\title{
Factors associated with bicycle ownership and use: a study of six small U.S. cities
}

\author{
Susan L. Handy • Yan Xing • Theodore J. Buehler
}

Published online: 21 April 2010

(C) The Author(s) 2010. This article is published with open access at Springerlink.com

\begin{abstract}
As a means of transportation and as a form of physical activity, bicycling generates benefits to the bicyclist as well as to the community as a whole. Bicycling now accounts for less than 1 percent of all trips for all purposes in the U.S., but evidence from other western countries suggests that under the right conditions, bicycling levels can be significantly higher. Indeed, the experiences of some U.S. cities suggest that it is possible to create conditions conducive to higher levels of bicycling even in the U.S. However, the extent to which bicycle investments have contributed to bicycling levels in these communities has not been rigorously assessed. The purpose of this study is to provide a better understanding of the determinants of bicycle ownership and use as a basis for identifying ways to promote bicycling. A cross-sectional study of six cities was designed to test the importance of bicycle infrastructure and other physical environment factors relative to individual factors and social environment factors, using a nested logit model to examine ownership and use decisions jointly. The results show strong effects of individual attitudes and physical and social environment factors on bicycle ownership and use.
\end{abstract}

Keywords Bicycle ownership - Bicycle use - Attitudes · Physical environment · Social environment

\footnotetext{
S. L. Handy ( $\square)$

Department of Environmental Science and Policy, University of California Davis, Davis, CA 95616, USA

e-mail: slhandy@ucdavis.edu

Y. Xing - T. J. Buehler

Institute of Transportation Studies, University of California Davis, Davis, CA 95616, USA

e-mail: yxing@ucdavis.edu

T. J. Buehler

e-mail: tjbuehler@ucdavis.edu
} 


\section{Introduction}

One hundred and forty years after its invention, the bicycle remains an important element of the transportation system. First, the bicycle is a low-cost, low-polluting alternative to driving that makes efficient use of limited roadway capacity. Second, for individuals who do not have the option of driving, the bicycle can be an effective means for getting places, particularly for trips that are too long for walking or are not served by transit (Murphy and Knoblauch 2004). Bicycling also plays a role in public health as a source of physical activity at a time when physical activity is declining and levels of obesity are reaching epidemic proportions (Killingsworth 2003). Bicycling, particularly bicycling for transportation, generates benefits to the bicyclist as well as to the community as a whole. Encouraging more bicycling, assuming this can be done safely and at reasonable expense, is thus a desirable societal goal.

At this point, the U.S. averages 0.39 bicycles per person, much lower than the 1.0 bicycles per person found in the Netherlands. ${ }^{1}$ Bicycling accounts for less than 1 percent of all trips for all purposes in the U.S., according to the 2000 National Household Transportation Survey (Pucher and Renne 2003). Shares of trips by bicycle in European countries are anywhere from four times (in the U.K., France, and Italy) to 28 times (in the Netherlands) that of the U.S. (Pucher and Dijkstra 2003). Although bicycling is popular in some parts of the U.S., more than two-thirds of this bicycling is for recreation rather than transportation; the percentages of bicycling trips for work, school, and shopping in the Netherlands (60.0\%) and in Germany $(60.1 \%)$ are twice that in the US $(30.5 \%)$ (Pucher and Dijkstra 2000).

These differences are not surprising, given differences in the physical and social environments in these countries compared with the U.S. (Pucher and Dijkstra 2000; Pucher and Buehler 2006; Pucher and Buehler 2008). This raises an important question for transportation planners in the U.S.: can they create conditions within the U.S., within the context of its physical and social environments, that will increase bicycle ownership and use, especially bicycling for transportation? In fact, some U.S. cities have substantial amounts of bicycling: the share of commuters usually bicycling to work, according to the 2000 U.S. Census, was $14.4 \%$ in Davis, CA, 6.9\% in Boulder, CO, and 5.5\% in Eugene, OR, compared to less than $1 \%$ for the U.S. overall. The extensive on-street and off-street bicycle networks in these towns undoubtedly helps to explain these relatively high levels of bicycling, but so might the strong bicycling culture in these communities (Buehler and Handy 2008). The relative importance of these factors has not been rigorously assessed.

This paper aims to fill that gap by examining factors influencing bicycle ownership and use in Davis, Boulder, Eugene, and three comparison cities. We use data collected through an on-line survey conducted in early fall 2006 to examine the relative influences of the physical and social environments, as well as individual factors, including socio-demographic characteristics and attitudes toward bicycling. The purpose of this paper is to provide a stronger empirical basis for the development of strategies to promote bicycling by contributing to an improved understanding of factors influencing the decision to own and use a bicycle.

\footnotetext{
${ }^{1}$ http://www.worldwatch.org/node/4057. Accessed 20 October 2009.
} 


\section{Conceptual basis and literature review}

For this study, the ecological model widely used in physical activity research within the field of public health provides a useful conceptual framework (Sallis and Owen 2002). This framework distinguishes between individual factors, social-environment factors, and physical-environment factors in explaining individual behavior. In addition to sociodemographic characteristics, individual factors include attitudes, preferences, and beliefs, as well as confidence in one's ability to engage in the behavior (a concept called "selfefficacy" in the field of public health). Social-environment factors include the cultural norms of the community, as evidenced by the collective behaviors of its residents. Physical-environment factors in this case include transportation infrastructure and land use patterns.

These three sets of factors are hypothesized to directly affect bicycling behavior (Fig. 1). Individual factors contribute to the motivation to bicycle, while social and physical environment factors determine the quality of bicycling conditions and may enable and encourage bicycling, or hinder and discourage it (Handy 1996; Handy 2009). From the perspective of travel behavior theory, bicycle infrastructure influences the utility of bicycling for an individual, affecting travel time, safety, comfort, enjoyment, and other qualities of the bicycling experience that may be important to an individual when deciding whether or not to bicycle. Communities invest in bicycle infrastructure in order to increase the utility of bicycling and thus increase the likelihood that individuals choose bicycling over other options. Note that these factors may affect each other over time; a supportive social environment for bicycling, for example, may lead to community investments in bicycle infrastructure, while good infrastructure, in turn, may help to generate a supportive environment.

Previous studies provide evidence of associations between factors at all three levels and both bicycle ownership and bicycle use (Table 1). Bicycle ownership has been less often studied than bicycle use, and bicycle use has been measured in many different ways. Here we review studies that focus on whether or not someone rides a bicycle rather than the frequency of bicycling or bicycle mileage. The dependent variables in these studies include binary measures of bicycling at least once a week (Moudon et al. 2005) or bicycling at least

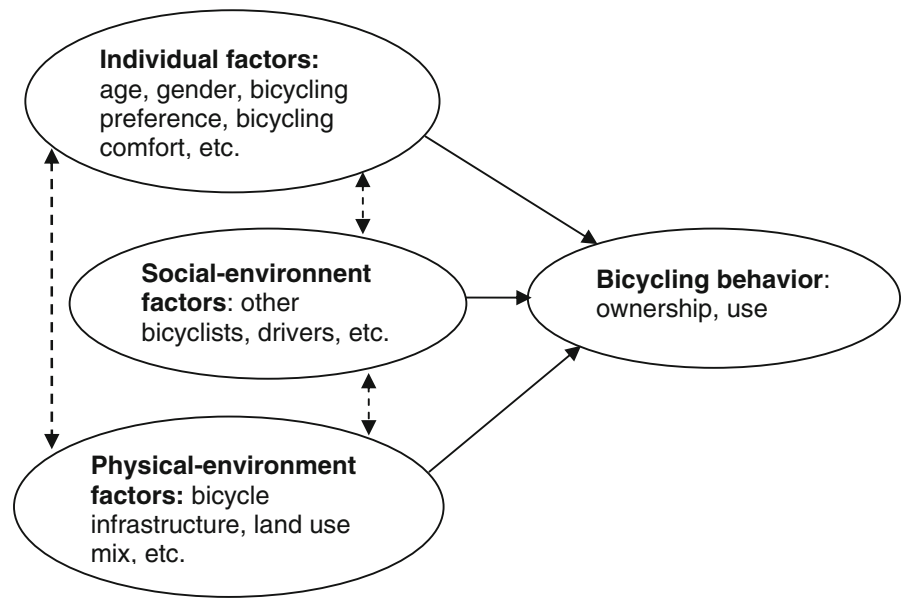

Fig. 1 Conceptual model 
Table 1 Factors associated with bicycle ownership and use in previous studies

\begin{tabular}{lll}
\hline & Bicycle ownership & Bicycle use \\
\hline Individual factors & Age & Gender \\
& Rousehold income & Age \\
& & Education level \\
& & Income \\
& & Transit use \\
& & Vehicles per person \\
Physical environment factors & Bicycle-friendly neighborhood & Physically active \\
& Traffic conditions & In good health \\
& & External self-efficacy \\
& Ecological-economic awareness \\
& & Land-use mix \\
& & Retail and service density \\
& & Urban location \\
& & Distance to bike facilities \\
& & Bicycle lanes \\
& & Separated bike paths \\
& & Bike-friendly design \\
& & Traffic conditions
\end{tabular}

once on a randomly selected day (Krizek and Johnson 2006), for studies using the individual as the unit of analysis, or share of commuters bicycling to work for the city as the unit of analysis (Dill and Carr 2003). Most studies of bicycling use focus on transportation bicycling, especially bicycle commuting; fewer studies have looked directly at factors influencing non-transportation bicycling.

At the individual level, socio-demographic factors are more commonly examined than are attitudinal factors or other kinds of individual factors. Bicycle ownership is associated with age, household income, and race in one study (Pinjari et al. 2008). Bicycle use in general is associated with gender, age, education level, and income (Krizek and Johnson 2006), as is bicycle use for transportation more specifically (Goldsmith 1992; Williams and Larson 1996; Plaut 2005; Wardman et al. 2007; Niemeier et al. 1995). One study found that bicycle use is associated with transit use, vehicles per person, being physically active, and being in good health (Moudon et al. 2005). Geus et al. (2008) provide the only available evidence on attitudes and bicycle use: external self-efficacy (as indicated by the willingness to cycle even if the weather is bad) and ecological-economic awareness (agreement that cycling is cheaper, better for the environment, etc.) were associated with bicycle commuting.

Characteristics of the physical environment are also associated with bicycle ownership and use. Although the physical environment is not measured in consistent ways across the studies, several clear patterns emerge. Bicycle infrastructure, in the form of separated bike paths and bike lanes (Dill and Carr 2003; Parkin et al. 2008), is associated with bicycle use, as is proximity to on-street bicycle lanes (Krizek and Johnson 2006). Retail and service density (Cervero and Duncan 2003), and urban location (Stinson and Bhat 2004) all relate to the average separation between residences and potential destinations, suggesting that distance plays an important role in explaining transportation bicycle use. Land use patterns and bicycle infrastructure are also associated with recreational bicycle 
use (Kamphuis et al. 2008). Traffic conditions are tied to bicycle ownership (Beck and Immers 1994) and bicycle commuting (Deakin 1985; Parkin et al. 2008), while bicyclefriendly design correlates with bicycling commuting and with recreational bicycling (Cervero and Duncan 2003; Kamphuis et al. 2008). Features of the natural environment, e.g. darkness (Cervero and Duncan 2003) and weather (Stinson and Bhat 2004), also correlate with bicycle use.

In contrast, few studies have examined associations between the social environment and bicycle ownership and use, and the results have been mixed. Not surprisingly, bicycle theft is tied to bicycle ownership (Beck and Immers 1994), mostly likely through both the direct effect of having a bicycle stolen and the deterrent effect that theft has on purchasing another bicycle. Geus et al. (2008) examined the connection between attitudes and bicycle use, but found only one factor that seemed to matter: people with relatives who give social support through bicycling together were more likely to bicycle for transportation. Other aspects of the social environment, such as social support through encouraging cycling, social influence on cycling, and social norms related to transportation bicycling, tested in Geus et al. (2008), and social support for cycling in the neighborhood, as measured in Moudon et al. (2005), were not associated with regular bicycling.

Although these studies provide important insights into factors influencing bicycle ownership and use, they have notable shortcomings. So far, studies have not fully examined the influences of the social environment on bicycling ownership and use, nor have they fully examined the role of individual attitudes and preferences. Of particular interest is the potential role of residential preferences: does a preference for bicycling lead individuals to choose a bicycling friendly community when deciding where to live? If so, then an observed association between the built environment and bicycling is driven by residential preferences rather than the environment itself. This possibility, called the "self-selection effect," has been documented in studies of walking as well as travel behavior more generally (Cao et al. 2009). Furthermore, most studies have looked at bicycle ownership and/or bicycle use separately, without considering the possibility of a simultaneous or sequential ordering of decisions. To our knowledge, ours is the first empirical study to address each of these issues.

It is also important to note that because these studies use cross-sectional designs, they establish associations between these factors and bicycle ownership and use, but they do not on their own establish the existence of a causal relationship. For example, an association between bicycle infrastructure and share of bicycle commuters at the city level (Dill and Carr 2003) could mean that infrastructure encourages bicycling or that bicycling encourages investments in infrastructure or some combination of both. Establishing causality requires more sophisticated research designs, ideally quasi-experimental studies that evaluate changes in bicycle ownership and use from before to after the opening of a new bicycle facility or some other type of "intervention" designed to increase bicycling. Unfortunately, rigorous studies of bicycle interventions are rare (Pucher et al. 2010), and they are difficult to carry out in practice (Krizek et al. 2009). Cross-sectional studies provide important guidance as to the most promising factors to target in designing interventions: all else equal, changes in factors with strong associations with bicycle use are more likely to lead to changes in bicycle use than are factors with weak associations with bicycle use (of course, other considerations also come into play, such as the cost and ease of changing the targeted factor). Cross-sectional studies, like ours, are thus an important step towards the design of effective strategies for increasing bicycling ownership and use. 


\section{Methodology}

This study employs a cross-sectional research design to determine the relative influence of individual, physical-environment, and social-environment factors on bicycle ownership and use. The unit of analysis for the study is the individual. The sample is made up of residents of Davis, Boulder, Eugene and three comparison communities that differ with respect to their physical and social environments. This approach enables an assessment of the direct relationships between these variables and bicycle ownership and use. In this analysis we will control for the possibility of "self-selection", that is, the possibility that residents of a city choose to live there in part because of the supportive bicycling environment. We do not otherwise account for potential relationships between the explanatory variables, called endogeneities, described earlier.

\section{Survey sampling and administration}

Six communities were selected for the study based on several factors. Davis, CA with a high bicycling level, was selected as a starting point. We then looked for comparison cities that were similar with respect to size, weather, topography, and presence of a college or university but differed with respect to bicycle infrastructure and culture. No communities perfectly fit our criteria. Chosen as comparison communities were Woodland, just 10 miles to the north of Davis, Chico, about $2 \mathrm{~h}$ north of Davis, and Turlock, a few hours to the south. Woodland has a relatively high level of bicycle infrastructure, while Chico has a supportive bicycling culture; Turlock has neither. In addition, we included Eugene, OR and Boulder, $\mathrm{CO}$ as comparison cities. Both cities have extensive bicycle infrastructure and enjoy reputations as bicycling communities nearly equal to Davis' reputation. This set of cities ensures reasonable comparability with respect to control variables but ample variation with respect to key explanatory variables, as shown below. Individual-level variations will be accounted for in the analyses.

For each of the six communities, we purchased a random sample of 1500 residents from Martin Worldwide, a commercial provider; for Davis, we ordered an additional sample of 1000 residents who had moved in the previous year. Participants were recruited for the online survey by mail in June 2006, with two reminder postcards mailed in July and August. As an enticement for participation, respondents could choose to be entered into a drawing for one of three $\$ 100$ prizes. Of the original 10,000 addresses, over 2000 proved to be incorrect, as evidenced by the return of the letter to UC Davis. After accounting for these bad addresses, we achieved a response rate of over $10 \%$ in every city except Turlock, where the response rate was just $7.2 \%$, with a high of $18.8 \%$ in Davis. The overall response rate for the survey was $12.6 \%$, for a sample size of 965 .

Given the relatively low response rate, non-response bias is a serious concern. The survey results show that $32 \%$ of Davis respondents usually commute to work by bike, in comparison to $14 \%$ in the 2000 Census; the survey share was higher than the census share for all cities except Turlock (Table 2). To evaluate the non-response bias further, a short phone survey was conducted in May 2008 in Davis only. Random-digit dialing was used to achieve a representative sample of 400 residents. The results show slightly lower bicycling levels (measured in various ways) than from the online survey (Table 3). The Chi-square tests indicate that bicycling levels in the two surveys are not different at the $5 \%$ significance level, implying that the non-response bias of the data from the online survey is not as serious as Table 2 suggests. Further, because the focus of our study is on explaining bicycle behavior as a function of other variables rather than on describing the simple 
Table 2 Bicycling levels: census (2000) and online survey (2006)

\begin{tabular}{lllllll}
\hline & Davis & Chico & Woodland & Turlock & Eugene & Boulder \\
\hline $\begin{array}{l}\text { Census } \\
\text { Share usually biking to work }\end{array}$ & & & & & & \\
$\begin{array}{l}\text { Survey } \\
\text { Share usually biking to work }\end{array}$ & $14.4 \%$ & $5.2 \%$ & $2.0 \%$ & $1.1 \%$ & $5.5 \%$ & $6.9 \%$ \\
$\begin{array}{l}\text { Share owning bicycle } \\
\text { Share biking in last 7 days }\end{array}$ & $32.3 \%$ & $13.7 \%$ & $7.2 \%$ & $0.0 \%$ & $17.8 \%$ & $22.7 \%$ \\
Share transportation-oriented bicyclists & $78.0 \%$ & $67.4 \%$ & $55.3 \%$ & $60.9 \%$ & $72.3 \%$ & $80.5 \%$ \\
$\quad$ in last 7 days & $53.0 \%$ & $37.3 \%$ & $20.2 \%$ & $12.0 \%$ & $37.7 \%$ & $50.0 \%$ \\
Share non-transportation-oriented bicyclists & $21.5 \%$ & $25.9 \%$ & $13.6 \%$ & $9.8 \%$ & $19.2 \%$ & $29.5 \%$ \\
$\quad$ in last 7 days & & $10.4 \%$ & $4.8 \%$ & $2.2 \%$ & $16.9 \%$ & $16.3 \%$ \\
Number of respondents & 354 & 135 & 125 & 92 & 130 & 129 \\
Response rate & $18.8 \%$ & $11.7 \%$ & $10.2 \%$ & $7.2 \%$ & $12.1 \%$ & $12.2 \%$ \\
\hline
\end{tabular}

Table 3 Davis bicycling level: phone survey (2008) versus online survey (2006)

\begin{tabular}{llll}
\hline & Phone survey & Online survey & $\begin{array}{c}\text { Chi-square test } \\
P \text {-values }\end{array}$ \\
\hline Share bicycle ownership & $76.3 \%$ & $78 \%$ & 0.576 \\
Share biking in last 7 days & $47.0 \%$ & $53.0 \%$ & 0.101 \\
Share biking within last year & $72.5 \%$ & $74.1 \%$ & 0.630 \\
Share biking to work & $29.5 \%$ & $32.3 \%$ & 0.502 \\
Number of respondents & 400 & 354 & \\
Response rate & $100 \%$ & $18.8 \%$ & \\
\hline
\end{tabular}

univariate distribution of bicycling per se, these differences are not expected to materially affect the results (Babbie 1998).

Definitions of variables

In our survey, $71.5 \%$ of the total valid respondents $(N=965)$ own or have regular access to a bicycle. The survey also takes a "snapshot" of bicycling behaviors of respondents within the previous 7 days. For the 690 "bicycle owners", people who reported bicycling at least once within the last 7 days are labeled "regular bicyclists"; the others are considered to be "non-regular bicyclists". The survey data show that $56.2 \%$ of the 690 respondents who reported owning bicycles are regular bicyclists, and $43.8 \%$ are nonregular bicyclists (Table 2). Respondents were classified as transportation-oriented bicyclists and non-transportation-oriented bicyclists based on a survey question that asked the respondents about their portion of bicycling for transportation and recreation purposes, in this way: "What portion of your bike rides are for transportation (commuting, shopping, visiting people) and what portion are for recreation (exercise, pleasure rides, adventure)? By 'bike ride' we mean a time you ride a bicycle for 5 min or more." Five choices were offered: 1. All bike rides for transportation. 2. Most bike rides for transportation. 3. About half and half for each. 4. Most bike rides for recreation. 5. All bike rides for recreation. For 
people who bicycled within last 7 days, respondents who chose options 1 or 2 are labeled transportation-oriented bicyclists, and the rest are labeled non-transportation-oriented bicyclists. The dependent variable was defined as comprising four categories: 1 -Does not have a bike; 2 - Has bike(s) but does not bike regularly; 3 - Has bike(s) and is a regular transportation-oriented bicyclist; 4-Has bike(s) and is a regular non-transportationoriented bicyclist. Even though the interest here is in understanding factors associated with being a regular transportation-oriented bicyclist, it is important to separate the non-regular transportation-oriented bicyclists into categories 2 and 4 given fundamental differences between them.

Explanatory variables fall into four categories: individual factors including sociodemographics and attitude factors, physical-environment factors, social-environment factors, and city-specific dummy variables (see Appendix for descriptions of all explanatory variables tested). For several variables, such as "Biking is Normal", indexes were created from a set of survey questions, either through factor analysis or simple mathematical computation (e.g. taking a count or averaging); alternative indexes were tested for significance in the model and tested for internal consistency using Cronbach's alpha. The city dummy variables were included to pick up city-specific characteristics associated with bicycling that are unmeasured in our survey; Turlock, with the lowest level of bicycling, was designated as the reference group, based on the suggestion of Hardy (1993). All variables tested in the models are included in the Appendix, including those that were not statistically significant.

It is important to note that we use perceptions of bicycle infrastructure rather than objective measures. Studies show that perceptual and objective measures of the built environment are closely correlated (Kirtland et al. 2003; Leslie et al. 2005). Theoretically, perceptions mediate the relationship between the environment and behavior and may have a more direct impact on behavior than objective measures of the environment (Bauman et al. 2002). Ideally, both perceptions and objective measures would be tested in the models (McCormack et al. 2004), and objective measures would reflect the specific residential locations of each respondent rather than general community characteristics. The resources needed to develop such measures were not available for this project. The percent of respondents reporting "entirely true" or "mostly true" for each of the bicycle infrastructure items in the survey are reported for each city in Table 4. Note that these percentages vary significantly across the cities, with a few exceptions. Perception of hilliness is equal across the California cities. The college towns do not differ with respect to perceptions of bike rack availability, lighting of streets and bike paths, signal buttons or sensors for bicyclists and pedestrians, and the lack of gaps in the bicycle network, though they do differ with respect to perceptions of bike lanes, street widths, offs-street bike paths, obstacles in bike lanes, and hilliness.

\section{Model selection}

Among the four categories of the dependent variable, some categories share common elements, e.g. respondents in both categories 1 and 2 did not bicycle within the last 7 days; respondents in categories 2, 3, and 4 share the common characteristic of owning bicycles. Therefore, four potential nested logit (NL) model structures were tested (Fig. 2). However, we could not find a satisfactory model for the 3-level nesting structure (NL1). Nesting structures 2 and 3 collapsed because the inclusive value (IV) parameters of the best NL models for them were not significantly different from 1 (i.e., the model 
Table 4 Perceptions of bicycle infrastructure by city—percent reporting "entirely true" or "mostly true"

\begin{tabular}{|c|c|c|c|c|c|c|c|c|}
\hline & $\begin{array}{l}\text { Davis } \\
(\%)\end{array}$ & $\begin{array}{l}\text { Chico } \\
(\%)\end{array}$ & $\begin{array}{l}\text { Wood- } \\
\text { land }(\%)\end{array}$ & $\begin{array}{l}\text { Turlock } \\
(\%)\end{array}$ & $\begin{array}{l}\text { Eugene } \\
(\%)\end{array}$ & $\begin{array}{l}\text { Boulder } \\
(\%)\end{array}$ & $\begin{array}{l}P \text {-value } \\
\text { across } \\
\text { CA cities }\end{array}$ & $\begin{array}{l}P \text {-value } \\
\text { across } \\
\text { college } \\
\text { towns }\end{array}$ \\
\hline Major streets have bike lanes & 90.6 & 47.0 & 49.6 & 51.1 & 90.6 & 76.2 & 0.000 & 0.000 \\
\hline $\begin{array}{l}\text { Streets without bike lanes } \\
\text { are wide enough to bike on }\end{array}$ & 72.1 & 38.9 & 43.4 & 44.2 & 66.1 & 56.5 & 0.000 & 0.006 \\
\hline $\begin{array}{l}\text { Stores and other destinations } \\
\text { have bike racks }\end{array}$ & 80.8 & 56.6 & 39.4 & 30.9 & 82.0 & 78.9 & 0.000 & 0.822 \\
\hline $\begin{array}{l}\text { Streets and bike paths are } \\
\text { well lighted }\end{array}$ & 67.5 & 43.9 & 39.3 & 33.8 & 65.3 & 59.7 & 0.000 & 0.308 \\
\hline $\begin{array}{l}\text { Intersections have push-buttons } \\
\text { or sensors for bicycles or } \\
\text { pedestrians }\end{array}$ & 83.3 & 76.9 & 69.2 & 69.8 & 85.6 & 83.2 & 0.002 & 0.825 \\
\hline $\begin{array}{l}\text { The city has a network of } \\
\text { off-street bike paths }\end{array}$ & 85.2 & 57.4 & 9.6 & 14.9 & 92.0 & 94.4 & 0.000 & 0.010 \\
\hline Bike lanes are free of obstacles & 73.3 & 68.7 & 41.2 & 47.9 & 90.8 & 88.7 & 0.000 & 0.000 \\
\hline $\begin{array}{l}\text { The bike route network has } \\
\text { big gaps }\end{array}$ & 17.5 & 38.5 & 65.3 & 61.4 & 23.2 & 19.8 & 0.000 & 0.453 \\
\hline $\begin{array}{l}\text { The area is too hilly for easy } \\
\text { bicycling }\end{array}$ & 1.8 & 1.6 & 3.4 & 2.4 & 1.7 & 8.1 & 0.713 & 0.001 \\
\hline
\end{tabular}

was not different from the multinomial logit model). The only nested model that holds is NL4. The choices of non-regular bicyclist, regular and transportation-oriented bicyclist, and regular and non-transportation-oriented bicyclist fall within one common nest, indicating that unobserved variables for the three choices are correlated. This makes sense given that the three groups are likely to share common characteristics related to owning a bicycle.

\section{Limitations}

This study is fundamentally limited by its cross-sectional design. Although we have controlled for the possibility of "self-selection" in this study, it is also possible that, for example, if an individual lives in a community with a strong bicycle culture and with good bicycle infrastructure, his preferences for bicycling increase over time. Other potential endogeneities among the factors (shown by the double-headed arrows in Fig. 1) were also ignored in this analysis. Further, potential sampling bias and low response rates in some cities (especially Turlock) may also weaken the significance of this study. The greater number of respondents from Davis and Boulder means that the sample has a disproportionate share of residents with relatively good bicycling conditions; the sample of residents with poor conditions, i.e. in Turlock, is small. Because the study uses data from small U.S. cities, the results may not be generalizable to urban areas or rural areas or to cities outside the U.S. It is also notable that the subjective measures of the environment may rely heavily on respondents' experiences of bicycling. For example, it is possible that the more an individual bicycles, the more likely he is to find flaws in the bicycle infrastructure. 


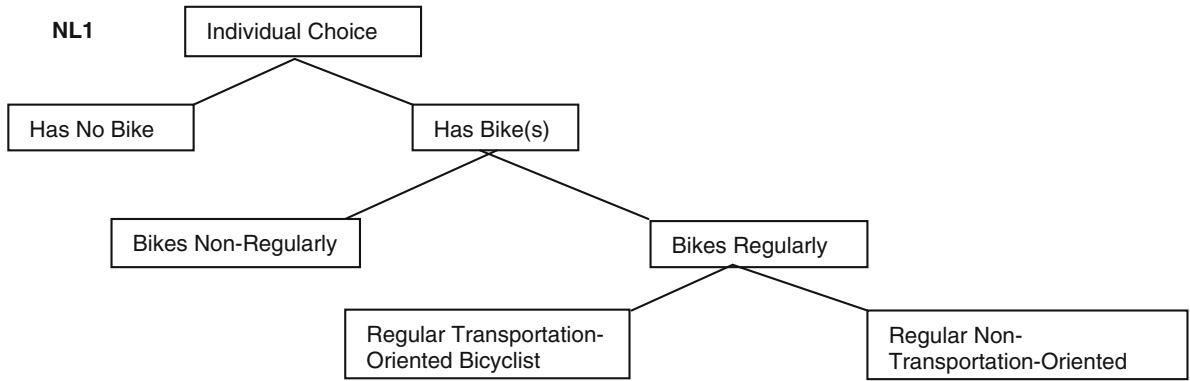

NL2
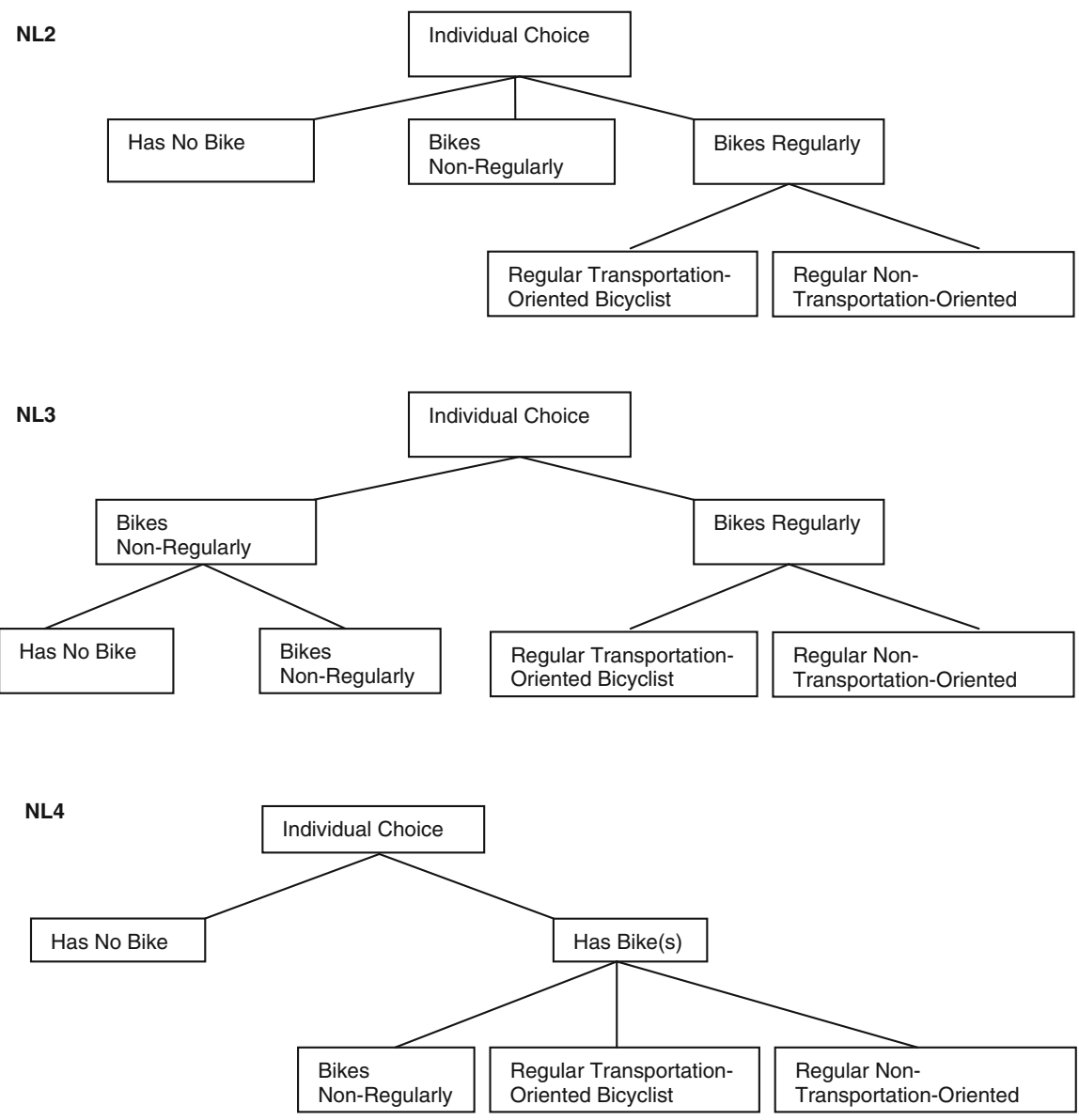

Fig. 2 Potential nested logit model structures

\section{Results}

The best-fitting model for bicycle ownership and use is shown in Table 5. The rho-squared value, measuring the model fit, is 0.211 , a value considered good for disaggregate models 
Table 5 Nested logit model for bicycle ownership and use

\begin{tabular}{|c|c|c|}
\hline Explanatory variables & Coefficient & $t$-statistic \\
\hline \multicolumn{3}{|c|}{ Variables specific to choice of having no bike } \\
\hline Constant & 15.709 & 2.357 \\
\hline Like biking & -3.908 & -1.614 \\
\hline \multicolumn{3}{|c|}{ Variables specific to choice of having bike but not biking regularly } \\
\hline Constant & 5.238 & 4.542 \\
\hline Like biking & -1.083 & -5.958 \\
\hline Like walking & 0.532 & 3.040 \\
\hline Bikers poor & 0.277 & 1.908 \\
\hline \multicolumn{3}{|c|}{ Variables specific to regular and transportation-oriented bicyclists } \\
\hline Constant & 0.727 & 0.378 \\
\hline Age & -0.041 & -3.827 \\
\hline Education level & 0.341 & 3.027 \\
\hline Biking comfort & 1.629 & 3.165 \\
\hline Environmental concern & 0.400 & 3.015 \\
\hline Need car & -0.165 & -2.134 \\
\hline Bike community preference & 0.481 & 2.512 \\
\hline Distances & -1.095 & -4.262 \\
\hline Bike network & 0.658 & 3.826 \\
\hline Free obstacle & -0.575 & -2.940 \\
\hline Kids bike & -0.254 & -1.805 \\
\hline Bikers not concerned with safety & 0.296 & 2.285 \\
\hline \multicolumn{3}{|c|}{ Variables specific to regular and non-transportation-oriented bicyclists } \\
\hline Good health & 0.521 & 3.752 \\
\hline Bike network & 0.304 & 2.660 \\
\hline Nesting coefficient & 0.837 & $-2.041 *$ \\
\hline \multicolumn{3}{|l|}{$N=571$} \\
\hline \multicolumn{3}{|c|}{ Log-likelihood at convergence $=-594.1482$} \\
\hline \multicolumn{3}{|c|}{ Log-likelihood with constants only $=-774.1208$} \\
\hline \multicolumn{3}{|c|}{ Adjusted rho-squared $=0.211 ;$ rho-squared $=0.232$} \\
\hline
\end{tabular}

* $t$-statistic tests that the coefficient is significantly different from 1 rather than zero

Dependent variable: Does not have a bike; Has bike(s) but does not bikes regularly; Has bike(s) and is a regular transportation-oriented bicyclist; Has bike(s) and is a regular non-transportation-oriented bicyclist (base)

with four alternatives. This value indicates that about $21 \%$ of the information contained in the data has been explained by this model. The final nesting coefficient is 0.837 and, correspondingly, the estimated correlation of unobserved variables for the three alternatives within the nest is 0.299 .

Factors specific to not owning a bicycle

Only one variable is significant in explaining bicycle ownership. A positive attitude toward bicycling_- "Like Biking", measured as agreement with the statement "I like riding a bike" - has a negative influence on not owning a bicycle. The more people like riding a 
bicycle, the less likely they are to not own a bicycle (e.g. the more likely they are to own one). No physical or social environment factors influence bicycle ownership. Bicycle ownership appears to depend solely on individual attitudes towards bicycling, at least within the context of these six cities.

Factors specific to regular bicycling

A higher level of agreement with the statement "I like riding a bike" is associated with a lower likelihood of non-regular bicycling. This attitude thus plays an important role in explaining both bicycle ownership and regular use. Those who like walking are less likely to bicycle regularly, perhaps because walking and cycling are substitutable forms of exercise and/or travel, at least for short trips. The model also shows that the social environment influences regular bicycle use: the perception that "Most bicyclists look like they are too poor to own a car" positively correlates with non-regular bicycling, controlling for all other factors. This suggests that negative perceptions of other bicyclists are a deterrent to regular bicycling, even for those who own a bicycle.

Factors specific to regular transportation-oriented bicyclists

Many individual factors are significant predictors of being a regular transportation-oriented bicyclist. Older age is associated with a lower likelihood of regular transportation-oriented bicycling, while education level has a positive effect, as might be expected in college towns. People with higher levels of bicycling comfort are more likely to bicycle regularly for transportation, as are those who report higher levels of environmental concern. Agreement that "I need a car to do many of the things I like to do" decreases the likelihood of being a regular transportation-oriented bicyclist. A preference for a bicycle community positively influences regular transportation bicycling: residents who chose their current living communities in part because of the supportive bicycling environment are more likely to be transportation-oriented bicyclists, suggesting a significant self-selection effect.

Several aspects of the physical environment also influence regular transportation bicycling. Longer distances to selected destinations, as determined by land use patterns, discourage transportation-oriented bicyclists. Bicycle infrastructure is also associated with transportation-oriented bicycling: agreement that "The city has a network of off-street bike paths" enters with a positive coefficient, indicating that a network of separated bike paths encourages transportation bicycling. Both findings are consistent with previous studies. Unexpectedly, the perception that bicycle lanes are free of obstacles discourages transportation bicycling. It is possible that regular bicyclists are more likely to notice obstacles along their routes. It is also possible that this finding is driven by the situation in Davis, where garden-waste is put directly in the street rather than in bins for collection but where a high share of residents bicycle for transportation nonetheless.

The model shows that social-environment factors also influence transportation bicycling. The perception that "Kids often ride their bikes around my neighborhood for fun" is negatively associated with transportation-oriented bicycling, controlling for all other factors. This perception might capture a recreational bicycling culture that disfavors bicycling for transportation; it might also or alternatively result from a physical environment conducive to bicycling within the neighborhood but not beyond, as is often found in suburban areas. The perception that "Many bicyclists appear to have little regard for their personal safety," which has a positive effect on transportation bicycling, may reflect an environment in which bicyclists do not need to be concerned for their safety, rather than an environment 
in which bicyclists are seen to be reckless. Other measures of the social environment were not significant, echoing results of previous studies that found limited significance of such factors.

Factors specific to non-transportation-oriented bicyclists

People who report that they are healthy are more likely to be non-transportation-oriented bicyclists, in other words, regular recreational bicyclists. The causal relationship underlying this correlation could go in either or both directions: healthier people are more likely to go for bicycle rides for recreation, and people who bicycle for recreation are likely to be healthier owing to the benefits of physical activity gained from bicycling. A network of separated bike paths is important for non-transportation-oriented bicycling, as it was for transportation bicycling, pointing to the importance of this form of infrastructure in encouraging regular bicycling. The fact that few variables were significant in explaining non-transportation-oriented bicycling is not surprising, given the focus of this study and thus the design of the survey instrument on factors affecting transportation-oriented bicycling. It is possible that other attitudinal, physical environment, and social environment factors not measured here are important in explaining recreational bicycling.

City specific dummy variables

After controlling for all these factors, city-specific dummy variables were insignificant in the final model, implying that the average effects of unobserved factors are similar across these cities.

\section{Conclusions}

This analysis provides new and potentially important insights into factors associated with the decision to own and use a bicycle regularly, for transportation or non-transportation purposes. The results demonstrate the significant role that individual factors, particularly individual attitudes, play. One of the important variables associated with bicycle ownership and regular use in the model is agreement with the statement, "I like riding a bike." The physical environment is also important, particularly distances to destinations as determined by land use patterns, for transportation bicycling, and a network of off-street bicycle paths, for bicycling for both transportation and recreational purposes. The model also shows significant effects of the social environment on bicycle use, though with respect to the perception of who else is bicycling rather than the perception that bicycling is common or normal in the community.

These findings suggest that a multifaceted approach to increasing bicycling is needed, one that focuses on the individual level as well as the social and physical environments. Most notably, they suggest that programs that aim to improve individual attitudes toward bicycling will be essential to increasing both bicycle ownership and regular use, even in communities with good bicycle infrastructure to begin with. More positive attitudes toward bicycling could be encouraged through promotional programs, such as Bike to Work Day and other events; such programs have reportedly had some lasting effect on bicycling (Bunde 1997; Rose and Marfurt 2007; Bauman et al. 2008). Bicycling comfort can be enhanced through training for bicyclists, for adults as well as children, leading to increases 
in bicycling (Telfer et al. 2006). A supportive social environment, also important for encouraging bicycling, can be created through promotional events, publicizing of highprofile role models, or even financial incentives to encourage bicycling for transportation. Such programs can also improve individual attitudes toward bicycling, producing an additional indirect effect on bicycle ownership and regular use.

At the same time, it seems unlikely that such programs would have much of an effect in communities without adequate bicycle infrastructure. Investments in a network of offstreet bicycle paths could encourage both transportation and recreational bicycling, particularly for less experienced bicyclists who express a preference for such facilities (Jackson and Ruehr 1998). Mixed land-use patterns that bring destinations within close distance of residences could also help to support transportation bicycling. The selfselection effect, in which residents who choose a community in part because of its bicycle orientation are more likely to be transportation-oriented bicyclists, also suggests an important role for bicycle infrastructure. Communities may succeed in increasing transportation bicycling by attracting more bicycle-oriented residents as well as by changing the behavior of existing residents. Thus, transportation planners must think more broadly about the physical environment, as more than just bicycle lanes or paths.

Our results suggest that while strategies targeting any one of the three levels-individual, social environment, physical environment - can help to increase bicycling, an approach that addresses all three levels is likely to be most effective. Indeed, those cities that have succeeded in increasing bicycling have employed a comprehensive package of strategies addressing factors at all three levels (Pucher et al. 2010). Copenhagen, for example, achieved a 70\% increase on bicycle trips between 1970 and 2006, with the share of trips by bicycle increase from $25 \%$ to $38 \%$. In Portland, OR, the number of bicyclists crossing the four bridges into downtown increased 369\% from 1992 to 2008. It seems likely that a package of strategies has synergistic effects, producing more total effect than the sum of the individual effect of each strategy on its own. Although most of these successful cities are found outside the U.S., the experiences of Davis, Boulder, Eugene, and Portland provide hope that a comprehensive approach can succeed in increasing bicycling in communities throughout the U.S.

Research on bicycling behavior is limited, particularly in comparison with the recent explosion of studies on walking (Saelens and Handy 2008) and given the potential of bicycling to fill important gaps in the transportation system (Handy 2009). This study offers valuable insights into the importance of individual, physical-environment, and social-environment factors in explaining bicycle ownership and use, but it also points to additional research needs. First, the significant role of individual attitudes shown here suggests a need for research into attitude formation. Why do some people like bicycling and others don't? What experiences lead to greater comfort riding a bicycle? Second, potential relationships between the factors examined here need exploration. To what degree does the physical environment shape the social environment, and vice versa? Does the environment, physical and/or social, influence individual attitudes? Finally, as strategies are implemented, before-and-after studies are needed to document their effects. Do new off-street bicycle paths really lead to an increase in bicycle use, as the documented associations suggest they will? The answers to these questions will help communities in their efforts to find effective strategies for increasing bicycling.

Acknowledgements The research was supported by a grant from the Sustainable Transportation Center at the University of California Davis, which receives funding from the U.S. Department of Transportation and Caltrans, the California Department of Transportation, through the University Transportation Centers 
program. Jamie Volker contributed to the development and implementation of the survey. Patricia Mokhtarian provided valuable guidance on model development and interpretation.

Open Access This article is distributed under the terms of the Creative Commons Attribution Noncommercial License which permits any noncommercial use, distribution, and reproduction in any medium, provided the original author(s) and source are credited.

\section{Appendix}

\section{See Table 6.}

Table 6 Description of variables tested in the model

\begin{tabular}{lll}
\hline Variable name & $\begin{array}{l}\text { \# Items } \\
\text { [range] }\end{array}$ & $\begin{array}{l}\text { Mean (s.d.) or Description } \\
\text { percent }^{\text {a }}\end{array}$
\end{tabular}

\begin{tabular}{|c|c|c|c|}
\hline \multicolumn{4}{|c|}{ Dependent variable } \\
\hline \multirow{4}{*}{$\begin{array}{l}\text { Bicycle } \\
\text { ownership and } \\
\text { regular use }\end{array}$} & $1[1,4]$ & $28.60 \%$ & $1=$ Does not have a bike \\
\hline & & $32.30 \%$ & $2=$ Has bike(s) but does not bike regularly \\
\hline & & $18.00 \%$ & $\begin{array}{l}3=\text { Has bike(s) and is a regular transportation-oriented } \\
\text { bicyclist }\end{array}$ \\
\hline & & $21.10 \%$ & $\begin{array}{l}4=\text { Has bike(s) and is a regular non-transportation- } \\
\text { oriented bicyclist }\end{array}$ \\
\hline
\end{tabular}

Explanatory variables

Individual factors: socio-demographics

\begin{tabular}{|c|c|c|c|}
\hline Age & $1[17,73]$ & $49.29(15.15)$ & Age in years \\
\hline Female & $1[0,1]$ & $44.00 \%$ & $1=$ Female $0=$ Male \\
\hline Education level & $1[1,6]$ & $4.45(1.86)$ & $\begin{array}{l}\text { The highest level of education. } 1=\text { Grade school or high } \\
\text { school, } 2=\text { High school diploma, } 3=\text { College or } \\
\text { technical school, } 4=\text { Four-year degree or technical } \\
\text { school certificate, } 5=\text { Some graduate school, } \\
6=\text { Completed graduate degree(s) }\end{array}$ \\
\hline Household size & $1[1,6]$ & $2.41(1.19)$ & The number of persons living in the household \\
\hline Income & $1[5,125]$ & $71.05(37.68)$ & $\begin{array}{l}\text { The total annual household income. Continuous, in } \\
\text { thousands of dollars }\end{array}$ \\
\hline Car ownership & $1[0,1]$ & $96.70 \%$ & $\begin{array}{l}\text { Car ownership. } 0=\text { Have no cars, } 1=\text { Have one or more } \\
\text { cars }\end{array}$ \\
\hline Home own & $1[0,1]$ & $75.50 \%$ & Own or rent the current residence. $0=$ Rent, $1=$ Own \\
\hline White & $1[0,1]$ & $82.00 \%$ & $1=$ white, not of Hispanic origin, $0=$ all others \\
\hline
\end{tabular}

Individual factors: attitudes

Biking comfort $\quad 6[1,3] \quad 2.40(0.39)$

Average comfort biking on an off-street path or quiet street, two-lane-local-street with or without bike lane, four-lane-street with or without bike lane, on 3-point scale where $1=$ Uncomfortable and I wouldn't ride on it, 2 = Uncomfortable but I'd ride on it, $3=$ Comfortable

Safety concern $5[1,3] \quad 1.66(0.43) \quad$ Average concern of being hit by a car, being hit by another bicyclist while biking, being bitten by a dog, being mugged or attacked, or crashing because of road hazards on 3-point scale where $1=$ Not at all concerned. $2=$ Somewhat concerned. $3=$ Very concerned

Good health $\quad 1[1,5] \quad 3.91(0.99) \quad$ Agreement that "I am in good health" on 5-point scale 
Table 6 continued

\begin{tabular}{|c|c|c|c|}
\hline Variable name & $\begin{array}{l}\text { \# Items } \\
\text { [range] }\end{array}$ & $\begin{array}{l}\text { Mean (s.d.) or } \\
\text { percent }^{\text {a }}\end{array}$ & Description \\
\hline Biked in youth & $1[0,1]$ & $97.00 \%$ & $\begin{array}{l}\text { "Did you ever ride a bicycle when you were about } \\
12 \text { years old", } 0=\text { no, } 1=\text { yes }\end{array}$ \\
\hline Like biking & $1[1,5]$ & $3.82(1.05)$ & Agreement that "I like riding a bike" on 5-point scale ${ }^{b}$ \\
\hline Like driving & $1[1,5]$ & $3.68(1.05)$ & Agreement that "I like driving" on 5-point scale \\
\hline Need car & $1[1,5]$ & $4.13(0.87)$ & $\begin{array}{l}\text { Agreement that "I need a car to do many of the things } \\
\text { I like to do" on 5-point scale }{ }^{\text {b }}\end{array}$ \\
\hline Limit driving & $1[1,5]$ & $3.41(1.05)$ & $\begin{array}{l}\text { Agreement that "I try to limit driving as much as } \\
\text { possible" on 5-point scale }{ }^{\mathrm{b}}\end{array}$ \\
\hline Like walking & $1[1,5]$ & $4.00(0.85)$ & Agreement that "I like walking" on 5-point scale ${ }^{\mathrm{b}}$ \\
\hline Like transit & $1[1,5]$ & $2.61(1.10)$ & Agreement that "I like taking transit" on 5-point scale ${ }^{\mathrm{b}}$ \\
\hline $\begin{array}{l}\text { Environmental } \\
\text { concern }\end{array}$ & $1[1,4]$ & $3.36(1.10)$ & $\begin{array}{l}\text { Importance of environmental benefits when choosing } \\
\text { mode, on } 4 \text {-point scale where } 1=\text { Not at all important, } \\
2=\text { Somewhat important, } 3=\text { Important, } \\
4=\text { Extremely important }\end{array}$ \\
\hline Pro-exercise & $2[1,5]$ & $4.24(0.86)$ & $\begin{array}{l}\text { Average agreement that "It's important to get regular } \\
\text { physical exercise" and "I enjoy physical exercise" on } \\
\text { 5-point scale }\end{array}$ \\
\hline $\begin{array}{l}\text { Bike community } \\
\text { preference }\end{array}$ & $1[1,4]$ & $1.80(0.97)$ & $\begin{array}{l}\text { Importance of "a good community for bicycling" when } \\
\text { choosing the residential location, on } 4 \text {-point scale where } \\
1=\text { Not at all important, } 2=\text { Somewhat important, } \\
3=\text { Important, } 4=\text { Extremely important }\end{array}$ \\
\hline \multicolumn{4}{|c|}{ Physical-environment factors } \\
\hline Bike lane & $1[1,4]$ & $3.01(0.92)$ & $\begin{array}{l}\text { Perceived trueness that "Major streets have bike lanes" on } \\
\text { 4-point scale }\end{array}$ \\
\hline Wide street & $1[1,4]$ & $2.65(0.90)$ & $\begin{array}{l}\text { Perceived trueness that "Streets without bike lanes are } \\
\text { generally wide enough to bike on" on 4-point scale }\end{array}$ \\
\hline Bike rack & $1[1,4]$ & $2.85(0.85)$ & $\begin{array}{l}\text { Perceived trueness that "Stores and other destinations } \\
\text { have bike racks" on 4-point scale }\end{array}$ \\
\hline Bike light & $1[1,4]$ & $2.55(0.85)$ & $\begin{array}{l}\text { Perceived trueness that "Streets and bike paths are well } \\
\text { lighted" on 4-point scale }\end{array}$ \\
\hline Push button & $1[1,4]$ & $3.08(0.80)$ & $\begin{array}{l}\text { Perceived trueness that "Intersections have push-buttons } \\
\text { or sensors for bicycles or pedestrians" on 4-point scale }\end{array}$ \\
\hline Bike network & $1[1,4]$ & $3.03(1.08)$ & $\begin{array}{l}\text { Perceived trueness that "The city has a network of off- } \\
\text { street bike paths" on 4-point scale }{ }^{c}\end{array}$ \\
\hline Free obstacle & $1[1,4]$ & $2.88(0.86)$ & $\begin{array}{l}\text { Perceived trueness that "Bike lanes are free of obstacles" } \\
\text { on 4-point scale }{ }^{c}\end{array}$ \\
\hline Bike gap & $1[1,4]$ & $2.12(0.95)$ & $\begin{array}{l}\text { Perceived trueness that "The bike route network has big } \\
\text { gaps" on 4-point scale }\end{array}$ \\
\hline $\begin{array}{l}\text { Hilly } \\
\text { topography }\end{array}$ & $1[1,4]$ & $1.17(0.49)$ & $\begin{array}{l}\text { Perceived trueness that "The area is too hilly for easy } \\
\text { bicycling" on 4-point scale }{ }^{\mathrm{c}}\end{array}$ \\
\hline $\begin{array}{l}\text { Safe } \\
\text { destinations }\end{array}$ & $5[1,3]$ & $2.41(0.68)$ & $\begin{array}{l}\text { Average perception of safety bicycling to "your usual } \\
\text { grocery store", "the nearest post office", "the local } \\
\text { elementary school", "a restaurant you like", "the } \\
\text { nearest bike shop" on 3-point scale where } \\
1=\text { Uncomfortable and I wouldn't ride there, } \\
2=\text { Uncomfortable but I'd ride there anyway, } \\
3=\text { Comfortable }\end{array}$ \\
\hline
\end{tabular}


Table 6 continued

\begin{tabular}{clll}
\hline Variable name & $\begin{array}{c}\text { \# Items } \\
\text { [range] }\end{array}$ & $\begin{array}{l}\text { Mean (s.d.) or } \\
\text { percent }^{\mathrm{a}}\end{array}$ & Description \\
\hline Distances & $6[1,4]$ & $2.39(0.57)$ & $\begin{array}{c}\text { Average perception of distances from home to "your usual } \\
\text { grocery store", "the nearest post office", "a restaurant } \\
\text { you like", "a bike repair shop", "your workplace", "the } \\
\text { local elementary school" on 4-point scale where } \\
1=\text { Less than a mile, } 2=1-2 \text { miles, } 3=2-4 \text { miles, } \\
4=\text { More than 4 miles }\end{array}$
\end{tabular}

Transit access $1[0,1] \quad 79.20 \%$

Social-environment factors

Good driver
attitude

$2.81(0.63)$

There is bus or train service within a 5 min walk of home. $0=$ No, $1=$ Yes

Average agreement that "Most drivers [do not] seem oblivious to bicyclists"d, "Most drivers yield to bicyclists", "Most drivers watch for bicyclists at intersections", "Most people [do not] drive faster than the speed limit" $\mathrm{d}$ on 5-point scale ${ }^{\mathrm{b}}$

Biking is normal $2[1,5] \quad 2.76(0.97)$

Average agreement that "Bicycling is a normal mode of transportation for adults in this community" and "It is [not] rare for people to shop for groceries on a bike" $\mathrm{d}$ on 5-point scale ${ }^{\mathrm{b}}$

$\begin{array}{llll}\text { Kids bike } & 1[1,5] & 3.47(0.96) & \begin{array}{c}\text { Agreement that "Kids often ride their bikes around my } \\ \text { neighborhood for fun" on 5-point scale }\end{array} \\ \text { Bikers poor } & 1[1,5] & 2.03(0.89) & \begin{array}{c}\text { Agreement that "Most bicyclists look like they are too } \\ \text { poor to own a car" on 5-point scale }\end{array}\end{array}$

Bikers spend $\quad 1[1,5] \quad 2.85(0.85)$

Bikers not $\quad 1[1,5] \quad 2.91(1.10)$
concerned with safety

City specific dummy variables

$\begin{array}{llll}\text { Davis } & 1[0,1] & 36.68 \% & 1=\text { Live in Davis, } 0=\text { Not } \\ \text { Eugene } & 1[0,1] & 13.47 \% & 1=\text { Live in Eugene, } 0=\text { Not } \\ \text { Boulder } & 1[0,1] & 13.37 \% & 1=\text { Live in Boulder, 0= Not } \\ \text { Chico } & 1[0,1] & 14.99 \% & 1=\text { Live in Chico, } 0=\text { Not } \\ \text { Woodland } & 1[0,1] & 12.95 \% & 1=\text { Live in Woodland, } 0=\text { Not }\end{array}$

${ }^{\text {a }}$ Mean (s.d.) for continuous variables or percent for discrete variables

b 1 = Strongly disagree, 2 = Disagree, $3=$ Neutral, $4=$ Agree, $5=$ Strongly agree

c $1=$ Not at all true, $2=$ Somewhat true, $3=$ Mostly true, $4=$ Entirely true

${ }^{d}$ Indicates that the scale of the survey question was reversed in creating the index

\section{References}

Babbie, E.: The practice of social research, 8th edn. Wadsworth Publishing Company, Belmont, CA (1998) Bauman, A., Sallis, J., Dzewaltowski, D., Owen, N.: Toward a better understanding of the influences on physical activity: the role of determinants, correlates, causal variables, mediators, moderators, and confounders. Am. J. Prev. Med. 23, 5-14 (2002)

Bauman, A., Rissel, C., Garrard, J., Speidel, R., Fishman, E.: Cycling: getting Australia moving: barriers, facilitators and interventions to get more Australians physically active through cycling. Cycling Promotion Fund, Melbourne (2008) 
Beck, M., Immers, L.H.: Bicycling ownership and use in Amsterdam. Transp. Res. Rec. 1441, 141-146 (1994)

Buehler, T., Handy, S.L.: Fifty years of bicycle policy in Davis. Transp. Res. Rec. 2074, $52-57$ (2008)

Bunde, J.: The BikeBus'ters from Arhus, Denmark 'We'll park our cars for 200 years. In: Tolley, Rodney (ed.) The Greening of Urban Transport: Planning for Walking and Cycling in Western Cities. Wiley, Chichester, UK (1997)

Cao, X., Mokhtarian, P.L., Handy, S.L.: Examining the impacts of residential self-selection on travel behaviour: a focus on empirical findings. Transport Reviews 29, 359-395 (2009)

Cervero, R., Duncan, M.: Walking, bicycling, and urban landscapes: evidence from the San Francisco Bay area. Am. J. Public Health 93, 1478-1483 (2003)

Deakin, E.A.: Utilitarian cycling: a case study of the Bay Area and assessment of the market for commute cycling. Research Report, University of California at Berkeley; California Department of Transportation; Federal Highway Administration, U.S. Department of Transportation (1985)

Dill, J., Carr, T.: Bicycle commuting and facilities in major U.S. cities: if you build them, commuters will use them. Transp. Res. Rec. 1828, 116-123 (2003)

Geus, B., Bourdeaudhuij, D.I., Jannes, C., Meeusen, R.: Psychosocial and environmental factors associated with cycling for transport among a working population. Health Educ. Res. 23, 697-708 (2008)

Goldsmith, S.A.: National bicycling and walking study, case study No. 1: reasons why bicycling and walking are not being used more extensively as travel modes. Report FHWA-PD-92-041. FHWA, U.S. Department of Transportation (1992)

Handy, S.L.: Urban form and pedestrian choices: a study of Austin neighborhoods. Transp. Res. Rec. 1552, 135-144 (1996)

Handy, S.L.: Walking, bicycling, and health. In: Malekafzali, S. (ed.) Healthy Equitable Transportation Policy. PolicyLink, Oakland, CA (2009)

Hardy, M.A.: Regression with Dummy Variables. Sage, Newbury Park, CA (1993)

Jackson, M.E., Ruehr, E.O.: Let the people be heard: San Diego County bicycle use and attitude survey. Transp. Res. Rec. 1636, 8-12 (1998)

Kamphuis, C.B., Giskes, K., Kavanagh, A.M., Thornton, L.E., Thomas, L.R., van Lenthe, F.J., Mackenbach, J.P., Turrell, G.: Area variation in recreational cycling in Melbourne: a compositional or contextual effect? J. Epidemiol. Community Health 62, 890-898 (2008)

Killingsworth, R.E.: Health promoting community design: A new paradigm to promote healthy and active communities. Am. J. Health Promot. 17, 169-170 (2003)

Kirtland, K.A., Porter, D.E., Addy, C.L., Neet, M.J., Williams, J.E., Sharpe, P.A., Neff, L.J., Kimsey, C.D., Ainsworth, B.E.: Environmental measures of physical activity supports: perception versus reality. Am. J. Prev. Med. 24, 323-331 (2003)

Krizek, K., Johnson, P.J.: Proximity to trails and retail: effects on urban cycling and walking. J. Am. Plann. Assoc. 72, 33-42 (2006)

Krizek, K., Handy, S.L., Forsyth, A.: Explaining changes in walking and bicycling behavior: challenges for transportation research. Environ. Plann. B 36, 725-740 (2009)

Leslie, E., Saelens, B., Frank, L., Owen, N., Bauman, A., Coffee, N., Hugo, G.: Residents' perceptions of walkability attributes in objectively different neighbourhoods: a pilot study. Health Place 11, 227-236 (2005)

McCormack, G., Giles-Corti, B., Lange, A., Smith, T., Martin, K., Pikora, T.J.: An update of recent evidence of the relationship between objective and self-report measures of the physical environment and physical activity behaviors. J. Sci. Med. Sport 7, 81-92 (2004)

Moudon, A.V., Lee, C., Cheadle, A.D., Collier, C.W., Johnson, D., Schmid, T.L., Weather, R.D.: Cycling and the built environment, a US perspective. Transp. Res. D 10, 245-261 (2005)

Murphy, N.B., Knoblauch, R.: Hispanic pedestrian and bicycle safety. The Federal Highway Administration (FHWA) and National Highway Transportation Safety Administration, Washington, DC (2004)

Niemeier, D., Rutherford, G., Ishimaru, J.: An analysis of bicyclist survey responses from the Puget Sound Area and Spokane. Report 95.4. Washington State Transportation Commission, Olympia (1995)

Parkin, J., Wardman, M., Page, M.: Estimation of the determinants of bicycle mode share for the journey to work using census data. Transportation 35, 93-109 (2008)

Pinjari, A.R., Eluru, N., Bhat, C.R., Pendyala, R.M., Spissu, E.: Joint model of choice of residential neighborhood and bicycle ownership: accounting for self-selection and unobserved heterogeneity. Transp. Res. Rec. 2082, 17-26 (2008)

Plaut, P.O.: Non-motorized commuting in the US. Transp. Res. D 10, 347-356 (2005)

Pucher, J., Buehler, R.: Why Canadians cycle more than Americans: a comparative analysis of bicycling trends and policies. Transp. Policy 13, 265-279 (2006) 
Pucher, J., Buehler, R.: Making cycling irresistible: lessons from The Netherlands, Denmark and Germany. Transp. Rev. 28, 495-528 (2008)

Pucher, J., Dijkstra, L.: Making walking and cycling safer: lessons from Europe. Transp. Q. 54, 25-50 (2000)

Pucher, J., Dijkstra, L.: Promoting safe walking and cycling to improve public health: lessons from The Netherlands and Germany. Am. J. Public Health 93 (2003)

Pucher, J., Renne, J.L.: Socioeconomics of urban travel: evidence from the 2001 NHTS. Transp. Q. 57, 49-77 (2003)

Pucher, J., Dill, J., Handy, S.L.: Infrastructure, programs, and policies to increase cycling: an International review. Prev. Med. 50, S105-S125 (2010)

Rose, G., Marfurt, H.: Travel behavior change impacts of a major ride to work day event. Transp. Res. Part A 41, 351-364 (2007)

Saelens, B., Handy, S.: Built environment correlates of walking: a review. Med. Sci. Sports Exerc. 40, S550-S566 (2008)

Sallis, J.F., Owen, N.: Ecological models of health behavior. In: Glanz, K., Rimer, B.K., Lewis, F.M. (eds.) Health Behavior and Health Education: Theory, Research, and Practice. Jossey-Bass, San Francisco, CA (2002)

Stinson, M.A., Bhat, C.R.: Frequency of bicycle commuting: internet-based survey analysis. Transp. Res. Rec. 1878, 122-130 (2004)

Telfer, B., Rissel, C., Bindon, J., Bosch, T.: Encouraging cycling through a pilot cycling proficiency training program among adults in central Sidney. J. Sci. Med. Sports 9, 151-156 (2006)

Wardman, M.R., Tight, M.R., Page, M.: Factors influencing the propensity to cycle to work. Transp. Res. A 41, 339-359 (2007)

Williams, J., Larson, J.: Promoting bicycle commuting: understanding the customer. Transp. Q. 50, 67-78 (1996)

\section{Author Biographies}

Susan L. Handy is Professor in Environmental Science and Policy and Director of the Sustainable Transportation Center at the University of California, Davis. Her research interests focus on the relationships between transportation and land use, particularly the impact of land use on travel behavior.

Yan Xing is a doctoral student in the Transportation Technology and Policy program at the University of California, Davis. Her dissertation uses structural equation modeling to examine interrelationships in the factors that influence bicycling behavior.

Theodore J. Buehler received his M.S. in the Transportation Technology and Policy program at the University of California, Davis in 2008. He is the founder of DavisBicycles!, an advocacy group in Davis, CA. 